\title{
IMPLIKASI INSTRUMEN NON-ZAKAT (INFAQ, SEDEKAH DAN WAKAF) DALAM PEREKONOMIAN
}

\author{
Nufi Mu'tamar Almahmudi ${ }^{1}$
}

\section{Abstrak}

Dalam ekonomi Islam, zakat merupakan salah satu instrumen yang mempunyai implikasi terhadap perekonomian. Namun ada bentuk non zakat yang mempunyai implikasi terhadap perekonomian yaitu infak, sedekah dan wakaf. Infak, sedekah maupun wakaf merupakan upaya untuk mewujudkan keadilan ekonomi di luar zakat. Tulisan ini mencoba menyajikan uraian terkait implikasi instrument non zakat dalam perkembangan hukum ekonomi syariah terhadap perekonomian menggunakan metode deskriptif analisis. Dengan adanya instrumen infak, sedekah maupun wakaf berarti kekayaan itu didistribusikan dari kalangan orang-orang kaya kepada orang-orang fakir. Hasil pengelolaan dana infak, sedekah maupun wakaf dalam bentuk yang produktif dapat dimanfaatkan secara lebih luas dalam rangka kesejahteraan masyarakat banyak dan bisa diaplikasikan sebagai pembangunan ekonomi meliputi program-program pemberdayaan umat, pengentasan kemiskinan, pendidikan, kesehatan dan lain-lain.

Kata Kunci: Implikasi, Non-zakat, Ekonomi

\section{Abstract}

In Islamic economics, zakat is an instrument that has implications for the economy. But there are non-zakat forms which have implications for the economy, namely infaq, alms and endowments. Infaq, alms and endowments are efforts to realize economic justice outside of zakat. This paper tries to present a description related to the implications of non-zakat instruments in the development of sharia economic law on the economy using descriptive analysis methods. With the infaq, alms and endowments instruments means that wealth is distributed from among the rich to the needy. The results of the management of infaq, alms and endowment funds in a productive form can be utilized more broadly in the context of the welfare of the community at large and can be applied as economic development including programs to empower people, alleviate poverty, education, health and others.

Keywords: Implications, Non-zakah, Economy

${ }^{1}$ Pascasarjana IAIN Purwokerto, Email: oppimutamar@gmail.com 


\section{A. PENDAHULUAN}

Perekonomian merupakan suatu hal yang penting bagi seseorang maupun lembaga atau instansi pemerintah dalam kehidupan. Perekonomian sangat berperan penting dikarenakan jika rendahnya ekonomi seseorang maka biasanya taraf kehidupannya pun juga rendah. Sebaliknya jika tingginya perekonomian seseorang biasanya taraf kehidupan seseorang tersebut juga tinggi. Dengan demikian, dalam kehidupan ini tidak bisa terlepas dari persoalan perekonomian. Permasalahan ekonomi selalu tidak pernah habisnya untuk dibahas karena berhubungan dengan angka kemiskinan. Kemiskinan menjadi hal yang sangat ditakuti oleh setiap orang karena kemiskinan berdampak kepada permasalahan multidimensional berupa pendidikan, sosial, kesehatan, dan politik.

Permasalahan ekonomi adalah hal yang krusial bagi kehidupan baik secara individu, masyarakat dan negara. Kesejahteraan dan ketenteraman hidup suatu negara dapat dilihat dari gambaran ekonomi masyarakatnya. Dalam perekonomian tidak jauh dari kata-kata keuangan. Keuangan merupakan alat yang sangat vital bagi kehidupan seseorang. Biasanya keuangan identik dengan harta dan dengan harta identik dengan sudut pandang orang yang menilai miskin ataupun kaya. Biasanya kaum yang tidak bisa mencukupi kehidupannya disebut duafa atau fakir miskin. Dalam hal ini sangat mendorong seseorang yang berlebihan harta untuk berbagi dengan orang lain (Muhammad 2009, 58).

Salah satu cara yang dapat meningkatkan perekonomian dan masalah kemiskinan adalah dengan memperdayakan umat melalui infak, sedekah, dan wakaf. Cara ini merupakan salah satu instrumen yang dapat menjadi solusi untuk mengurangi masalah perekonomian seperti kemiskinan. Oleh karena itu, tulisan ini akan membahas tentang implikasi infaq, sedekah, dan wakaf terhadap perekonomian.

\section{B. METODE PENELITIAN}

Penelitian ini merupakan riset kepustakaan (library research). Dalam hal ini, peneliti berbicara banyak, berdialog banyak dengan buku-buku, arsip-arsip, dokumen-dokumen, jurnal, catatan-catatan, dokumentasidokumentasi, surat-surat, dan lain-lain (Simanjutak 2014, 8). Adapun dalam menganalisis penelitian ini penulis menggunakan metode deskriptif analisis. Analisis deskripsi bertujuan untuk memberikan 
deskripsi mengenai subyek penelitian berdasarkan data dan variabel yang diperoleh dari kelompok subyek yang diteliti. Data-data yang diperoleh kemudian penulis analisis dengan mengaitkan antara intstrumen non zakat dan implikasinya terhadap perekonomian.

\section{IMPLIKASI INFAK-SEDEKAH-WAKAF TERHADAP PEREKONOMIAN}

Sebagai salah satu pilar dalam perekonomian, infak, sedekah dan wakaf memiliki fungsi yang sangat penting dalam pertumbuhan ekonomi. Ini tercermin pada dua konsep utama, yaitu pertumbuhan ekonomi berkeadilan dan mekanisme sharing dalam perekonomian. Tujuan utamanya adalah untuk meningkatkan kesejahteraan kaum duafa. Pada jangka pendek, kebutuhan kaum duafa dapat terpenuhi, sementara pada jangka panjang, daya tahan ekonomi mereka akan meningkat (Khairina 2019, 172). Dalam Undang-undang dinyatakan bahwa infak adalah harta yang dikeluarkan oleh seseorang atau badan usaha di luar zakat untuk kemaslahatan umum. Sedangkan sedekah adalah harta atau non harta yang dikeluarkan oleh seseorang atau badan usaha di luar zakat untuk kemaslahatan umum (Suma 2013, 257). Shadaqah dalam konsep Islam konsep Islam mempunyai arti yang luas, tidak hanya terbatas pada pemberian sesuatu yang sifatnya materiil kepada orang-orang miskin, tetapi shadaqah mencakup semua perbuatan kebaikan (Sari 2007, 5).

Infak dan sedekah mempunyai fungsi yang sama dengan zakat, tetapi jangkauannya lebih luas, dan lebih fleksibel. Infaq dan sedekah bukan saja diberikan kepada orang miskin muslim tetapi juga orang miskin non muslim, dan selain bisa digunakan untuk membantu kebutuhan yang bersifat konsumtif juga dapat digunakan untuk kegiatan produktif. Infaq dan sedekah dapat memberi mereka peluang kerja berupa bantuan modal/ peralatan kerja, bantuan pendidikan, bantuan fasilitas kesehatan, dan sebagainya sehingga nantinya mereka lebih produktif. Jika dikelola dengan baik maka akan mampu meningkatkan kesejahteraan masyarakat, meningkatkan etos dan etika kerja, serta sebagai institusi pemerataan ekonomi. Sehingga dimungkinkan untuk mengisi kekurangan, atau sebagai salah satu alternative dalam menanggulangi keterbatasan dana pemerintah (Multifiah 2011, 6). 
Dengan demikian, infaq, sedekah maupun wakaf merupakan upaya untuk mewujudkan keadilan ekonomi di luar zakat. Ketika masyarakat Islam telah makmur, kaya, maka mereka bisa membangun infrastruktur seperti lembaga pendidikan, pusat-pusat pelatihan, sarana ibadah, sarana industri dan lain-lain. Ketika ekonomi kuat, maka negara dapat makmur dan sebaliknya apabila terjadi ketidakadilan ekonomi dapat mengakibatkan kesejahteraan rakyat yang sejati tidak terwujud dan dapat menimbulkan kekacauan dimanamana.

Dampak ZIS atas kemaslahatan masyarakat dan perekonomian Islam sangatlah jelas. Karena dalam ZIS itu sendiri terdapat unsur pemberian bantuan kepada orang-orang fakir, disamping mewujudkan kepentingan yang bersifat umum. Ini dapat dilihat secara jelas dari pospos pendistribusian ZIS. Dengan ZIS berarti kekayaan itu didistribusikan dari kalangan orang-orang kaya kepada orang-orang fakir. Dengan cara seperti ini, maka terdapat unsur pemerataan kekayaan, sehingga kekayaan tidak menggelembung di pihak tertentu, sementara masih adanya kemelaratan di pihak lain.

Kemudian pembahasan lebih lanjut tentang wakaf yang merupakan salah satu amal jariyah yang memiliki peranan penting dalam bidang keagamaan sebagai bentuk ketaatan kepada Allah SWT. Di samping itu, wakaf juga merupakan salah satu pranata keagamaan yang mampu untuk mensejahterakan apabila dikelola secara profesional sesuai dengan peruntukan wakaf. Adapun keutamaan wakaf yaitu dapat menanamkan sifat zuhud dan melatih menolong kepentingan orang lain. Selain itu wakaf juga dapat menghidupkan lembaga-lembaga sosial dan keagamaan demi syiar Islam dan keunggulan kaum muslimin (Hujriman 2018, 5). Saat ini wakaf mempunyai potensi besar dalam membangun perekonomian negara karena harta wakaf berbentuk sesuatu yang bersifat produktif sehingga kegunaannya dapat dirasakan hingga masa yang akan datang. Khususnya dalam hal pengentasan kemiskinan, pemerataan pendidikan, mengurangi kesenjangan sosial dan perbaikan perekonomian. Dengan membaiknya perekonomian maka akan berimbas pada perbaikan kualitas hidup.

Berkaca dari negara Singapura yang telah berhasil memajukan komunitas muslimnya melalui pengelolaan wakaf yang professional dengan total asset mencapai SG\$ 500 milyar (Rp 3,5 trilyun). MUIS,

IMPLIKASI INSTRUMEN NON-ZAKAT (INFAQ, SEDEKAH DAN

20 WAKAF) DALAM PEREKONOMIAN

Nufi Mu'tamar Almahmudi 
lembaga wakaf di Singapura mengelola asset wakaf dengan membuat perumahan, perkantoran, pusat bisnis, hingga serviced apartement yang hasil keuntungannya dijadikan sumber pendanaan kegiatan sosial MUIS, diantaranya adalah kegiatan pembiayaan operasional masjid, pembelian lahan kuburan dan lain sebagainya (Rohman 2012, 3). Indonesia dinilai mampu melebihi Singapura karena luas wilayah dan jumlah penduduk Indonesia yang jauh lebih luas dan besar dibandingkan Singapura. Jumlah penduduk kelas menengah Indonesia yang tidak sedikit merupakan potensi besar yang bisa dimanfaatkan. Jika setiap orang sadar akan pentingnya wakaf, maka wakaf dapat dijadikan sebagai solusi untuk mengatasi maslah kemiskinan di Indonesia.

Dalam perkembanganya wakaf juga mempunyai bentuk lain yaitu wakaf tunai. Wakaf tunai adalah penyerahan hak milik berupa uang tunai kepada seseorang, kelompok orang atau lembaga nadzir untuk dikelola secara produktif dengan tidak mengurangi atau menghilangkan 'ain asset sehingga dapat diambil hasil atau manfaatnya oleh maukuf alaih sesuai dengan permintaan wakif yang sejalan dengan syariat Islam (Heykal 2010, 325). Wakaf tunai ini agar sesuai dengan harapan yang akan dicapai, maka implikasi penbelanjaan hasil wakaf mempunyai tiga efek (Mannan 2000, 43):

1. Efek "good deed", yaitu hasil wakaf hanya diserahkan dan dianggap sebagai amal baik.

2. Efek "Free rider", yaitu hasil wakaf tidak ada pembedaan antara orang kaya dan orang miskin.

3. Efek "Income Redistribution", operasionalisasi wakaf akan diperoleh sebuah realita bahwa telah terjadi distribusi pendapatan horizontal secara signifikan dari suatu kelompok pendapatan ke kelompok yang lain.

Pada dasarnya pengelolaan wakaf tunai secara efektif untuk pembangunan ekonomi itu terkait dengan opersionalnya. Hasil pengelolaan dana wakaf tunai dapat dimanfaatkan secara lebih luas dalam rangka kesejahteraan masyarakat banyak dan bisa diaplikasikan sebagai pembangunan ekonomi. Oleh karena itu, dana-dana segar yang didapatkan dari hasil pemberdayaan wakaf tunai tersebut tidak hanya untuk kepentingan yang selalu terkait dengan ibadah secara sempit seperti membangun masjid, musholla, makam, pondok pesantren dan 
lain-lain, tapi juga bisa dimanfaatkan untuk kepantingan umum. Maka untuk mengoptimalisasi wakaf tunai akan difokuskan pada dua aspek besar yaitu pembangunan yang bersifat fisik dan pemberdayaan dan pengembangan.

\section{IMPLIKASI INFAK-SEDEKAH PADA PENERIMAAN NEGARA}

Dana zakat, infak, dan sedekah (ZIS) memiliki potensi yang sangat luar biasa. Sebagai ilustrasi, untuk Indonesia saja dengan penduduk Muslim sekitar 212,5 juta (85\%) dari keseluruhan penduduk Indonesia yang berjumlah 250 jutaan jiwa (pada tahun 2013), dalam satu malam takbir (malam Idul Fitri) diper-kirakan akan mampu mengumpulkan dana zakat fitrah sekira 5,3 triliun rupiah, sebagai perkiraan dari perkalian jumlah penduduk Muslim sebanyak 212,5 juta jiwa itu dikalikan dengan Rp 25.000 untuk seharga 2,5 kilogram beras bagi setiap orang. Belum termasuk dana zakat mal, infak, sedekah dan lainlain (fidyah, kaffarah, dan sebagainya) yang hampir dapat dipastikan jumlahnya lebih banyak lagi dari itu. Berdasarkan riset BAZNAS, IDB, dan IPB beberapa waktu yang lalu, potensi ZIS Indonesia tahun 2011 saja bisa mencapai 217 triliyun rupiah. Ini menunjukkan bahwa potensi ZIS di Indonesia sesunguhnya sangat besar (Suma 2013, 271).

Dengan potensi tersebut, manajemen keuangan publik terdiri dari zakat, infak dan sedekah harus dilakukan dengan cermat, tepat dan hati-hati. BAZNAS harus mampu menjamin dan memberi kepastian seluruh dana masyarakat dengan baik sehingga akan semakin mendapat amanah dan kepercayaan dari masyarakat untuk mengelola dana ZIS yang merupakan sumber-sumber keuangan Islam. Sejarah mencatat bahwa ZIS merupakan salah satu instrument penting pembangunan pemerintahan Islam. Banyak program pemerintah dapat menggunakan dana ZIS, diantaranya program-program pemberdayaan umat, pengentasan kemiskinan, pendidikan, kesehatan dan pembangunan masjid (Widiastuti, Potensi Zakat Untuk APBN 2019). Infaq, sedekah dan wakaf merupakan pemberian sukarekla dari rakyat demi kepentingan umat untuk mengharapkan ridha Allah SWT semata. Pada kondisi keimanan rakyat yang begitu baik, maka dapat saja (besar kemungkinannya) penerimaan negara yang berasal dari variabel sukarela ini akan lebih besar dibandingkan dengan variabel wajib, sepanjang faktor-faktor produksi digunakan pada tingkat yang maksimal (Nurul Huda 2012, 216). 
Dengan demikian, bisa dilakukan integrasi dana ZIS dan APBN dalam membiayai pembangunan. Sinergi pemerintah dan lembaga ZIS akan membuat penyaluran ZIS lebih efektif. Lembaga ZIS akan berbagi dengan pemerintah dalam pemberdayaan dan pengentasan kemiskinan. Jika potensi dana ZIS itu bisa dimaksimalkan, pemerintah akan sangat terbantu membiayai pembangunan. Ini utamanya yang berkaitan dengan pengentasan kemiskinan, pendidikan dan kesehatan.

\section{E. IMPLIKASI WAKAF PADA INVESTASI}

Dalam kajian menegenai ekonomi Islam, secara umum yang dimaksud dengan istilah wakaf ialah menyerahkan sesuatu benda atau sebangsanya yang kekal zatnya guna diambil manfaatnya bagi kepentingan umum dan atau khusus (Kamal 2002, 189). Wakaf merupakan tindakan hukum yang dilakukan seseorang dengan mendonasikan sejumlah hartanya untuk dikelola sedemikian rupa. Pengeloalaan atas harta yang telah didonasikan tersebut bertujuan untuk menghasilkan keuntungan atau manfaat yang tidak hanya akan dinikmati untuk kepentingan keagamaan, tetapi dapat pula untuk aktivitas ekonomi dan sosial yang luas. Wakaf merupakan suatu bentuk investasi yang dapat diarahkan untuk aktivitas dan kebermanfaatan, baik dari sisi religious, ekonomis, maupun sosial. Optimalisasi wakaf akan memiliki implikasi positif terhadap investasi. Apabila diarahkan pada aktivitas produktif dan bernilai ekonomis, wakaf akan dapat menunjang investasi dan pemerataan pendapatan. Oleh karena itu ajaran wakaf mengharuskan penjagaan atas pokok harta, penggunaan pokok harta pada aktivitas produktif, serta distribusi keuntungan dan manfaat kepada masyarakat, khususnya kaum miskin yang membutuhkan (Pratiwi Utami 2018, 20-21). Sehingga wakaf yang diberikan oleh masyarakat tidak hanya dalam bentuk tanah (harta tidak bergerak). Dengan bentuk harta yang tidak bergerak tentunya sulit untuk mengembangkan harta wakaf tersebut.

Di Indonesia sendiri, peraturan perwakafan diatur dalam UndangUndang Nomor 41 Tahun 2004 Tentang Wakaf dan Peraturan Pemerintah Nomor 42 Tahun 2006 Tentang Pelaksanaan UndangUndang Nomor 41 Tahun 2004 Tentang Wakaf. Hadirnya UndangUndang No. 41 Tahun 2004 tentang wakaf memberikan pijakan hukum yang pasti, kepercayaan publik, serta perlindungan terhadap aset 
wakaf. Pengesahan undang-undang ini merupakan langkah strategis untuk meningkatkan kesejahteraan umum, meningkatkan peran wakaf, tidak hanya sebagai pranata keagamaan saja, tetapi juga memiliki kekuatan ekonomi yang potensial untuk memajukan kesejahteraan umum. Di samping itu, dengan disahkannya undangundang ini, objek wakaf lebih luas cakupannya tidak hanya sebatas benda tidak bergerak saja, tapi juga meliputi benda bergerak seperti uang, logam mulia, surat berharga, hak sewa dan sebagainya (Hazami 2016, 186-187).

Harta wakaf dapat digunakan lebih produktif sebab di dalamnya terkandung pemahaman dan pola managemen pemberdayaan potensi wakaf yang lebih modern. Dengan diaturnya wakaf dalam bentuk undang-undang, maka sektor wakaf dapat menjadi solusi alternatif peningkatan kesejahteraan sosial ekonomi masyarakat pengelolaan dan pengembangan harta wakaf bisa dilakukan secara produktif. Konsep wakaf produktif ini sangat penting untuk dikembangkan di Indonesia.

Wakaf produktif adalah wakaf yang bersifat memberikan dampak nilai yang panjang dan luas. Maksud dari panjang adalah dilihat dari sisi waktu pahala yang bisa didapat oleh wakif dan juga manfaat yang bisa diperoleh oleh para penerima manfaat. Sedangkan maksud dari luas adalah dilihat dari tidak terbatasnya wilayah penerima manfaatnya dan nilai kemanfaatannya. Salah satu contoh asset wakaf produktif yang telah dirasakan manfaatnya oleh masyarakat umum adalah tanah wakaf beserta gedung yang berdiri di atasnya yang diserahkan seorang donatur kepada Yayasan Sosial Madani Bali tahun 2006. Pemanfaatan tanah wakaf ini sempat kurang optimal pada awalnya dan hanya digunakan sebagai Taman Pengajian Al Qur'an bagi anak-anak yang tinggal di daerah sekitar pada hari tertentu. Pada awal 2010 pemanfaatan tanah wakaf ini lebih optimal dengan digunakan sebagai layanan kesehatan yang bernama Rumah Sehat Madani. Respon yang diberikan masyarakat terhadap unit program rumah sehat madani ini cukup besar terutama bagi kaum dhuafa yang memiliki keterbatasan mengakses layanan kesehatan dasar (Rohman 2012, 8). Mengingat luasnya jangkauan penerima manfaat wakaf produktif, maka sudah selayaknya wakaf produktif untuk disosialisasikan dikarenakan memberikan manfaat yang lebih besar kepada masyarakat. 
Sosialisasi pengenalan bentuk wakaf lain, berupa wakaf tunai, menjadi peristiwa cukup penting. Potensi wakaf yang ada saat ini, selain barang-barang tidak bergerak, seperti tanah, juga ada dalam bentuk wakaf tunai, dan dari sinilah potensinya dapat dipandang sebagai suatu instrument investasi yang fleksibel. Jika semua potensi wakaf yang ada digabung, baik berupa tanah, uang maupun barang berharga lainnya, akan menjadi suatu kekuatan yang luar biasa dalam mendorong tingkat pendapatan nasional. Sebagai sarana investasi, wakaf sangat berguna dalam melancarkan fungsi-fungsi financial intermediary, sehingga terjadi arus penyaluran dana yang lancar dan surplus unit kepada deficit unit dalam semua tingkat sosial. Aliran dana ini merupakan manifestasi prinsip profit distribution dan flow concept yang ditegaskan $\mathrm{Al}$ qur'an dengan adanya dua hal yang tabu dalam sistem ekonomi syariah, yairu: pertama, dilarangnya konsentrasi kekayaan hanya pada segelintir orang masyarakat, dan resistensi terhadap status idle (nganggur) bagi segenap sumber daya (Nawawi 2012, 246-247).

Wakaf tunai mempunyai peluang bagi terciptanya investasi di bidang keagamaan, pendidikan, dan pelayanan sosial. Di negaranegara muslim yang pengelolaan wakafnya lebih maju seperti, Mesir, Yordania, Saudi Arabia, Turki dan Bangladesh, wakaf tidak hanya dimanfaatkan dalam bentuk konsumtif tetapi juga dimanfaatkan dalam bentuk produktif. Selain sarana dan prasarana ibadah dan pendidikan wakaf juga dikembangkan dalam bentuk tanah pertanian, perkebunan, uang, saham, dan lain-lain, sehingga hasilnya benar-benar mampu mewujudkan kesejahteraan umat (Darwanto 2012, 7-8). Dengan demikian, diharapkan dari harta wakaf dapat memberikan manfaat yang lebih luas untuk mewujudkan keseimbangan kesejahteraan spiritual dan materiil dengan tujuan pada kesejahteraan dunia dan akhirat.

\section{F. KORELASI KEIMANAN DAN KINERJA EKONOMI}

Iman dan amal (kerja) tidak dapat dipisahkan, sebagaimana halnya lahir dan bathin. Demikianlah sehingga kita selalu menemukan kata yang bergandengan dalam Al-Qur'an antara kata iman dan amal shalih. Hubungan antara keduanya ibarat matahari dengan pancaran sinarnya, yaitu iman yang benar harus memancarkan amal shalih yaitu 
bekerja. Dan sebaliknya pekerjaan yang terbaik harus memancar dari iman yang benar (Ya'qub 1992, 3). Toto Tasmara telah menjelaskan dalam bukunya "Etos Kerja Pribadi Muslim" bahwa kelezatan iman akan terasa jika dimanifestasikan dalam bentuk amal shalih yaitu suatu bukti wujud aktivitas kerja kreatif, yang ditempa oleh semangat dan motivasi tauhid untuk mewujudkan identitas dan cita-citanya yang luhur sebagai umat yang terbaik (Tasmara 2012, 1).

Menurut bahasa, amal shalih tersebut dapat diartikan sebagai perbuatan atau pekerjaan yang baik. Dengan dorongan-dorongan tersebut, maka sudah seyogyanya umat Islam menjadi umat yang paling ulet, berbuat kebaikan dan rajin bekerja. Semua itu tentu dilakukan dalam rangka mendapatkan ridha Allah SWT (Ya'qub 1992, 3). Oleh karena itu, maka umat Islam secara keseluruhan dan bahkan yang memiliki keimanan tinggi sudah seharusnya melakukan kerja dengan rajin dan sungguh-sungguh. Sebagai umat Islam tentu segala sesuatu yang dilakukan harus sesuai dengan pedoman Islam, begitupun dalam bekerja. Bekerja yang merupakan fitrah manusia terutama umat Islam harus dijalankan dengan pondasi nilai-nilai keimanan dalam Islam yang bersumber dari Al-Qur'an dan As-Sunnah. Bekerja dengan pondasi keimanan inilah yang dinamakan dengan etos kerja Islami.

Pendekatan Islam terhadap ekonomi merupakan sebuah pendeketan terhadap peradaban manusia secara keseluruhan. Pendekatan ini sangat relevan untuk dilaksanakan dalam rangka membangun suatu sistem ekonomi alternatif guna mengganti sistem ekonomi yang sudah ada dan tidak mampu memberikan kesejahteraan kepada umat manusia. Landasan moral dan etika yang dibangun dalam kegiatan ekonomi Islam adalah sesuai dengan fitrah asal manusia yang progresif dan dinamis dan relevan sepanjang masa. Ekonomi Islam juga menawarkan metodologi yang layak untuk dijadikan pedoman dalam pembangunan ekonomi secara makro (Manan 2012, 36).

Problem terbesar pada dunia perekonomian adalah pada pengabaian nilai-nilai etika dalam mencari harta. Pola hidup hedonis (glamor) menumbuhkan sikap berlebihan dalam menggunakan sarana kesenangan yang beraneka ragam . Pada posisi ini kemewahan sudah ditempatkan sebagai kebutuhan. Pada saat itu hilangnya nilai moral dan mendominasinya nilai material. Sirkulasi dari aspek produksi, konsumsi serta distribusi hanya berkutat pada pemenuhan kebutuhan

IMPLIKASI INSTRUMEN NON-ZAKAT (INFAQ, SEDEKAH DAN 
yang serba prestise. Orang lupa akan batasan-batasan berekonomi, akhlak di kesampingkan karena menjadi penghalang dalam memenuhi kebutuhan. Pandangan skeptis terhadap nilai-nilai moral ini mestinya disingkirkan dari karakter orang yang berbudi dan beriman. Karena harta bukan semata ukuran dari kesejahteraan, walaupun di sana terdapat unsur tersebut, namun terpenting adalah terwujudnya keseimbangan dan ketenangan jiwa tanpa mengabaikan nilai uluhiah. Telah menjadi kesadaran orang mukmin bahwa harta adalah titipan Allah dan manusia hanya mengelola sebagai sarana beribadah kepadaNya (Karim 2018, 199). Materi dan moral merupakan sesuatu yang tidak dapat dipisahkan karena memang demikian yang seharusnya menjadi prinsip. Abdullah Zaky Al Kaff menyebutkan materi dan moral haruslah berjalan secara bersama agar terwujud ekonomi-sosial yang sehat dan teratur. Apabila materi berjalan secara menyendiri dalam melakukan aktivitas ekonomi dan hubungan manusia hanya diukur dengan harta semata maka yang terjadi suasana yang kapitalis. Begitu pula sebaliknya jika hanya dengan aspek moral saja tanpa materil, hilanglah kebutuhan dunia yang sangat dibutuhkan guna menciptakan kesejahteraan hajat dunia.

Berikut beberapa etika moral yang perlu diperhatikan dalam menjalankan transaksi ekonomi (Karim 2018, 201-213):

Pertama, Amanah. Dalam kamus besar Bahasa Indonesia, kata amanah diartikan dengan sesuatu yang dipercayakan kepada orang, keamanan atau ketentraman. Amanah merupakan sikap yang ada pada diri seseorang yang dengannya orang yang mempercayai merasa aman dan tentram atas sesuatu yang dikuasakan kepada orang yang memiliki sikap ini. Islam mengajarkan kepada kaum muslimin untuk berlaku konsekuen terhadap apa yang telah menjadi keputusannya. Sesuatu yang menjadi keputusannya harus dijalankan sesuai prosedur dan tidak menyalahi syariat. Keputusan untuk terjun dalam bidang ekonomi, mengharuskan setiap orang di dalamnya menjalankan segala aktivitas ekonomi dengan baik. Sikap amanah disini menjadi patokan berlangsungnya system ekonomi yang bersih. Prinsip amanah ini hanya akan terwujud pada diri mereka yang merasa bahwa apa yang sedang dijalankanya seperti wirausaha, bisnis, maupun bekerja, merupakan tanggung jawab yang harus dijalani sesuai dengan prosedur. Ia sadar bahwa yang sedang dijalankannya ada pada 
pengawasan, baik pengawasan manusia lebih-lebih pengawasan yang memberikan amanah yakni Allah SWT.

Kedua, Profesional. Upaya mencari harta dibutuhkan banyak skill dan keahlian yang bisa mendukung terselesaikannya pekerjaan dengan baik. Bachtiar Ali mengungkapkan bahwa professional merupakan pekerjaan yang menuntut pendidikan keahlian, intelektualitas dan tanggungjawab etias yang mandiri dalam prakteknya. Sikap professional dalam bekerja diapresiasi nabi dalam sabdanya "sungguh Allah senang jika salah seorang dari kalian mengerjakan suatu pekerjaan ia kerjakan secara itqan (tepat, terarah dan tuntas)". Begitu ajaran Islam telah mengarahkan manusia untuk menjadi pribadi yang professional. Profesi yang unggul disertai sikap yang berlandaskan keikhlasan bekerja dan berusaha sebagai mencari ridha Allah akan menumbuhkan semangat etos kerja, sikap ini akan menciptakan orang lain tertarik dan menghargai usahanya.

Ketiga, Tanggungjawab. Sikap tanggungjawab merupakan prinsip bagi seseorang dalam berekonomi. Sikap ini menjadikan seseorang disegani dan dipercaya. Seorang pekerja/ pengusaha bekerja bukan hanya mencari harta semata. Memang mendapatkan upah adalah konsekuensi logis dari apa yang diupayakannya namun jika hasil yang diperoleh sebatas mendapatkan uang tanpa mengindahkan pertanggungjawaban dalam kerjanya, maka hal ini adalah kezaliman.

Setiap muslim tidaklah akan bekerja hanya sekedar untuk bekerja, asal mendapat gaji atau bahkan sekedar menjaga gengsi supaya tidak disebut sebagai penganggur. Melainkan kesadaran bekerja secara produktif serta dilandasi semangat tauhid dan nilai-nilai keimanan inilah yang merupakan salah satu ciri yang khas dari karakter seorang muslim (Tasmara 2012, 4). Kedudukan bisnis dalam Islam juga sangat penting. Ayat-ayat al Qur'an dan Hadits banyak memuat tema bisnis sebagai kegiatan ekonomi yang tidak lepas dari kriteria agama itu sendiri. Islam sangat menekankan perdagangan yang jujur dan adil sebagai kegiatan mencari keuntungan, karena hal tersebut merupakan cerminan umat dalam merefleksikan agamanya (Sobirin 2002, 23). Dengan demikian menegakkan nilai-nilai etika dalam berekonomi sangatlah penting, agar terwujud kesejahteraan sosial, saling bahu membahu, bukan penindasan satu sama lain. Dengan ini perlunya perhatian manusia terhadap etika dan keimanan guna menjadi 
pencegah terjadinya kerusakan dalam melakukan aktivitas ekonomi yang ditimbulkan dari sikap manusia yang cenderung egois.

Oleh karena itu dapat diberikan kesimpulan sederhana bahwa umat Islam yang memiliki keimanan dalam dirinya, maka sudah selayaknya akan mengaplikasikan keimanannya dalam bentuk amal shalih, yaitu salah satunya dengan bekerja atau berbisnis. Sehingga dengan keimanan itulah umat Islam akan melakukan pekerjaan dengan karakter Islam atau yang disebut etos kerja Islami.

\section{G. PENUTUP}

Dalam perekonomian, infak, sedekah maupun wakaf merupakan upaya untuk mewujudkan keadilan ekonomi di luar zakat. Dengan adanya infak, sedekah maupun wakaf berarti kekayaan itu didistribusikan dari kalangan orang-orang kaya kepada orang-orang fakir. Dengan cara seperti ini, maka terdapat unsur pemerataan kekayaan, sehingga kekayaan tidak menggelembung di pihak tertentu, sementara masih adanya kemiskinan di pihak lain. Hasil pengelolaan dana infak, sedekah maupun wakaf dapat dimanfaatkan secara lebih luas dalam rangka kesejahteraan masyarakat banyak dan bisa diaplikasikan sebagai pembangunan ekonomi meliputi programprogram pemberdayaan umat, pengentasan kemiskinan, pendidikan, kesehatan dan lain-lain. Adapun upaya yang dilakukan untuk meningkatkan optimalisasi implikasi infak, sedekah dan wakaf tersebut terhadap perekonomian yaitu dengan memaksimalkan sosialisasi instrumen non zakat tersebut, dimana instrumen non zakat tersebut diarahkan menjadi bentuk yang produktif sehingga mempunyai manfaat yang lebih luas untuk kemaslahatan umat.

\section{DAFTAR PUSTAKA}

Darwanto. (2012). Wakaf Sebagai Alternatif Pendanaan Penguatan Ekonomi Masyarakat Indonesia. Jurnal Ilmu Manajemen Dan Akuntansi Terapan, 3(1).

Hazami, B. (2016). Peran dan Aplikasi Wakaf dalam Mewujudkan Kesejahteraan Umat di Indonesia. Jurnal Analisis, 16(1).

Huda, N. \& Heykal, M. (2010). Lembaga Keuangan Islam Tinjauan Teoretis dan Praktis. Jakarta: Kencana. 
Huda, N. et al. (2012). Keuangan Publik Islam: Pendekatan Teoritis dan Sejarah. Jakarta: Kencana.

Hujriman. (2018). Hukum Perwakafan di Indonesia. Yogyakarta: Deepublish.

Kamal, M., et al. (t.t) Fikih Islam. Yogyakarta: Citra Karsa Mandiri.

Karim, Bustanul. (2018). Prinsip Pembangunan Ekonomi Umat (Upaya Menggali Petunjuk Al Qur'an Dalam Mewujudkan Kesejahteraan). Yogyakarta: Diandra Kreatif.

Khairina, N. (2019). Analisis Pengelolaan Zakat, Infak, Dan Sedekah (ZIS) Untuk Meningkatkan Ekonomi Duafa (Studi Kasus di Lembaga Amil Zakat Nurul Hayat Cabang Medan) Jurnal AtTawassuth, 4(1).

Mannan, M.A. (2000). Sertifikat Wakaf Tunai Sebuah Inovasi Instrumen Keuangan Islam, Terj. Agus Mijanto dan Rozi Diyanti. Depok: Ciber PKTTI-UI.

Manan, A. (2012). Hukum Ekonomi Syariah Dalam Perspektif Kewenangan Peradilan Agama. Jakarta: Kencana.

Muhammad. (2009). Lembaga Keuangan Mikro Syariah. Yogyakarta: Graha Ilmu.

Multifiah. (2011). ZIS Untuk Kesejahteraan Umat. Malang: Ub Press.

Nawawi, I. (2012). Fikih Muamalah Klasik dan Kontemporer. Bogor: Ghalia Indonesia.

Rohman, F. (Ed). (2012). Wakaf Membangun Negeri. Bali: Madani.

Sari, E. K. (2007). Pengantar Hukum Zakat dan Wakaf . Jakarta: PT Grasindo.

Simanjutak, B. A. (t.t). Metode Penelitian Sosial (Edisi Revisi). Jakarta: Yayasan Pustaka Obor Indonesia.

Sobirin, A. (2002). Relevansi Ajaran Agama dalam Aktivitas Ekonomi (Studi Komparatif Antara Ajaran Islam dan Kapitalisme). Jurnal Iqtisad, 3(1).

Suma, M. A. (2012). Zakat, Infak, dan Sedekah: Modal dan Model Ideal, Jurnal Al-Iqtishad, 5(2).

Tasmara,T. (1994). Etos Kerja Pribadi Muslim. Jakarta: PT. Dana Bhakti Wakaf.

Utami, P. et al. (2018). Indonesia 2045 Pemikiran Terbaik Putra-Putri Bangsa untuk Ibu Pertiwi. Yogyakarta: Bentang Pustaka.

Widiastuti, T. (2019). Potensi Zakat untuk APBN dalam www.koranjakarta.com, di akses 6 Desember 2019.

IMPLIKASI INSTRUMEN NON-ZAKAT (INFAQ, SEDEKAH DAN

30 WAKAF) DALAM PEREKONOMIAN

Nufi Mu'tamar Almahmudi 
al-Mizan, Vol. 4, No.1, hlm. 17-31, Februari 2020, P.ISSN : 2085-6792, E.ISSN : 2656-7164

Ya'qub, H. (1992). Etos Kerja Islami; Petunjuk Pekejaan yang Halal dan Haram dalam Syari'at Islam. Jakarta: CV Pedoman Ilmu Jaya. 